\section{General methodological aspects in the Brazilian National Survey on Child Nutrition (ENANI-2019): a population-based household survey}

\author{
Aspectos metodológicos gerais do Estudo \\ Nacional de Alimentação e Nutrição Infantil \\ (ENANI-2019): inquérito domiciliar \\ de base populacional
}

\author{
Aspectos metodológicos generales del Estudio \\ Nacional de Alimentación y Nutrición Infantil \\ (ENANI-2019): encuesta domiciliaria \\ de base poblacional
}

\author{
Nadya Helena Alves-Santos 1 \\ Inês Rugani Ribeiro de Castro 2 \\ Luiz Antonio dos Anjos 3 \\ Elisa Maria de Aquino Lacerda 1 \\ Paula Normando 1 \\ Maiara Brusco de Freitas 1 \\ Dayana Rodrigues Farias 1 \\ Cristiano Siqueira Boccolini 4 \\ Maurício Teixeira Leite de Vasconcellos 5 \\ Pedro Luis do Nascimento Silva 5,6 \\ Gilberto Kac 1
}

doi: $10.1590 / 0102-311 \times 00300020$

\begin{abstract}
This article aims to present general methodological aspects of the Brazilian National Survey on Child Nutrition (ENANI-2019), from the conception of the study design to details of the data collection. This is a household-based population survey with a sample calculated at 15,000 households to identify children under five years of age, conducted in 123 municipalities in Brazil's 26 states and the Federal District. ENANI-2019 includes data on breastfeeding and dietary intake; anthropometric nutritional status of all children and their biological mothers; and nutritional status concerning the following micronutrients: iron (hemoglobin and ferritin), zinc, selenium, and vitamins A, $B 1, B 6, B 12, D, E$, and folic acid of children from 6 to 59 months of age. A total of 193,212 households were visited, of which 19,951 were eligible, and 12,524 were included in the study. A total of 14,558 children were studied, of whom 13,990 (96.1\%) and 13,921 (95.6\%) had their body mass and length/ stature measured, respectively, and 14,541 (99.9\%) underwent 24-hour dietary recalls (24HR). Of the 12,598 children eligible for blood sample collection, 8,739 (69.3\%) had at least one laboratory parameter measured. Data were collected from February 2019 to March 2020, when the survey was interrupted due to the COVID-19 pandemic. The evidence produced by the ENANI-2019 survey can back the formulation, follow-up, and/or reorientation of food and nutrition policies such as the promotion of breastfeeding and healthy eating and the prevention and control of different forms of malnutrition.
\end{abstract}

Infant; Preschool Child; Methods; Nutrition Assessment

\author{
1 Instituto de Nutrição Josué de Castro, Universidade Federal do \\ Rio de Janeiro, Rio de Janeiro, Brasil. \\ 2 Instituto de Nutrição, Universidade do Estado do Rio de \\ Janeiro, Rio de Janeiro, Brasil. \\ 3 Departamento de Nutrição Social, Universidade Federal \\ Fluminense, Rio de Janeiro, Brasil. \\ 4 Instituto de Comunicação e Informação Científica e \\ Tecnológica em Saúde, Fundação Oswaldo Cruz, Rio de Janeiro, \\ Brasil. \\ 5 Escola Nacional de Ciências Estatísticas, Instituto Brasileiro \\ de Geografia e Estatística, Rio de Janeiro, Brasil. \\ 6 Science - Sociedade para o Desenvolvimento da Pesquisa \\ Científica, Rio de Janeiro, Brasil.

\section{Correspondence} \\ G. Kac \\ Departamento de Nutrição Social e Aplicada, Instituto de \\ Nutrição Josué de Castro, Universidade Federal do Rio de \\ Janeiro. \\ Av. Brigadeiro Trompowsky s/n, Bloco J, 2 o andar, Rio de \\ Janeiro, RJ 21941-590, Brasil. \\ gilberto.kac@gmail.com
}




\section{Introduction}

The periodic nationwide assessment of food and nutrition indicators is essential for backing the formulation, monitoring the implementation, and when necessary, the reorientation of actions and programs within public policies, such as the Brazilian National Food and Nutrition Policy (PNAN) 1 and the Brazilian National Food and Nutrition Security Policy (PNSAN) 2.

Since the 1960s, Brazil has conducted national or subnational surveys on food, nutrition, and health in different population groups 3,4. Anthropometric and/or dietary intake data on children under five years of age were produced in the following national surveys: Interdepartmental Committee on Nutrition for National Development (1963) 4, Brazilian National Family Expenditures Survey (ENDEF), Brazilian Family Budgets Surveys (POF; 2002/2003, 2008/2009), Brazilian National Survey on Health and Nutrition (PNSN), all editions of the Brazilian National Demographic and Health Survey (PNDS), and the Brazilian National Health Survey (PNS) 5 .

These national surveys provided important evidence on the food and nutritional status of children under five years of age. However, they did not adequately address aspects related to the epidemiology of micronutrient deficiencies and dietary intake in this group, specific breastfeeding practices such as human milk donation and cross-nursing, and the consumption of vitamin and mineral supplements. In addition, the latest detailed survey on childhood health and nutrition was conducted in 20066.

The Brazilian Ministry of Health thus funded a new nationwide study called the Brazilian National Survey on Child Nutrition (ENANI-2019), with the objectives of assessing breastfeeding and dietary intake, anthropometric nutritional status, and micronutrient deficiencies in Brazilian children under five years of age. ENANI-2019 also assessed the anthropometric nutritional status of the children's biological mothers and a set of proximal determinants of childhood feeding and nutrition, such as sociodemographic characteristics, food insecurity, cooking skills, and the home and community food environments. ENANI-2019 will produce up-to-date evidence on relevant events and priority nutritional problems for the collective health agenda to reorient public policies and fill the abovementioned knowledge gaps.

The current article aims to present and discuss methodological aspects of the ENANI-2019's conception and overall organization, from the elaboration of the study design and sampling plan to the production of the data collection instruments, training activities, and details of the data collection. The manuscript also discusses the challenges for conducting a study with this scope and complexity from the perspective of assisting other researchers in planning future household surveys.

\section{Materials and methods}

\section{Study design, population, and sampling}

ENANI-2019 is a household-based population survey on food and nutrition in children under five years of age. The sample was calculated at 15,000 households distributed across 123 municipalities (counties) in Brazil's 26 states and the Federal District. The sample size, 3,000 households in each of the five major geographic regions, was defined to estimate a minimum proportion of $2 \%$ with a relative error of $35 \%$ (representing a range from $1.3 \%$ to $2.7 \%$ ), $95 \%$ confidence level, and sampling design effect set at 2. Brazil's 5,570 municipalities, stratified in state capitals, large municipalities (population $>500,000$ ), and other municipalities, were grouped by the major geographic regions. All the state capitals and large municipalities were included in the sample. In contrast, in the other strata, the municipalities were selected with probability proportional to the estimated number of children under five years of age on July 1, 2016. In the sampled municipalities, the census tracts were stratified by mean household income quartiles and selected with probability proportional to the number of children under five years of age, according to the 2010 Population Census, using Pareto sampling 7. The selection of households used an inverse sampling strategy until 10 households had been obtained in the tract or all the addresses in the tract had been visited, with any number of households interviewed $8,9,10$. The sample was designed to generate estimates per the major geographic regions. Details on the sampling plan are available in Vasconcellos et al. ${ }^{11}$. 
Certain target events such as childhood feeding practices and serum vitamin D levels display significant variation between seasons of the year 12,13. To guarantee a seasonal balance in the major geographic regions, insofar as possible, the survey planned the data collection distributed across seasons of the year in seven successive waves from February 2019 to March 2020, including the updating of the address registry.

The small number of children under five years of age in the selected census tracts interfered in the pace of data collection, and it was necessary to extend the end of the collection to May 2020. However, with the COVID-19 pandemic, the Executive Committee of ENANI-2019, together with the Brazilian Ministry of Health and the board of Science (Society for the Development of Scientific Research; http://www.science.org.br), responsible for the data collection in the field, decided to terminate the data collection in March 2020, when approximately $83.5 \%$ of the calculated sample had been achieved.

\section{General aspects of the study}

ENANI-2019 is structured in three domains: (i) assessment of breastfeeding and dietary intake, applying structured questionnaires with questions on breastfeeding and foods consumed on the day prior to the interview, and a 24-hour dietary recall (24HR); (ii) anthropometric assessment of nutritional status, measuring the length/stature and body mass of the children and their biological mothers; and (iii) assessment of micronutrient deficiencies, collecting blood samples from children 6 to 59 months of age by venipuncture and performing complete blood count and determination of ferritin, C-reactive protein (CRP), zinc, selenium, vitamin A, B1, B6, B12, D, and E, and folic acid levels. For each of the domains, an expert group was established with professors from public universities to support the study's Executive Committee on decisions pertaining to methodological and/or operational aspects of the respective domain.

Data were also collected on the children's demographic characteristics and their families' socioeconomic characteristics and variables consisting of the following: (1) National Economic Indicator 14; (2) the child's gestational, birth, and medical history; (3) childhood development 15; (4) consumption of vitamin and mineral supplements at the time of the study and in the previous six months; (5) mother's total fertility rate, prenatal history, and information on breastfeeding practices in the youngest child in the household; (6) home cooking; (7) home food environment 16,17; (8) community food environment; and (9) household food insecurity (Box 1). Figure 1 shows the timeline of activities in ENANI-2019.

\section{Visual identity and communication strategies}

The visual identity of the ENANI-2019 survey was based on a central graphic display with the childhood growth curves elaborated by the World Health Organization (WHO) 18 and adopted by the Brazilian Ministry of Health. All the materials produced for the study (manuals, leaflets, correspondence, $t$-shirts, websites) used the logomark and followed the manual for the study's logomark and visual identity.

Communications by the ENANI-2019 with different stakeholders included complementary channels and strategies. ENANI-2019 profiles were created in the principal social networks (Instagram, Facebook, and Twitter - @enani2019) for communication with the population and reports on the survey in the municipalities where the survey was happening. A toll-free (0800) hotline was provided to orient the population on receiving the test results, answering questions about participation in the study, and recording complaints of rumors and fake news that circulated in some of the municipalities participating in the study.

A communications consultancy firm (In Media Comunicação; http://inmediacomunica.com.br/) was hired to support interaction between the ENANI-2019 and municipal and state governments, personnel staff in the Brazilian Unified National Health System (SUS), and the media. This firm assisted the Executive Committee of ENANI-2019 in the dialogue and interaction with staff from the Brazilian Ministry of Health, the Military Police in various states, the Brazilian National Security Force, and the community health agents and other healthcare workers in the municipalities the study 
Box 1

Data collected in the general questionnaire in the Brazilian National Survey on Child Nutrition (ENANI-2019).

\begin{tabular}{|c|c|}
\hline SECTIONS & DATA COLLECTED \\
\hline National Economic Indicator & $\begin{array}{l}\text { Data on the presence of household assets, housing characteristics, } \\
\text { and residents' characteristics (such as schooling) for use as a proxy } \\
\text { to characterize the household wealth index, that is, the capacity for } \\
\text { permanent consumption }\end{array}$ \\
\hline Gestation, birth, medical history & $\begin{array}{c}\text { Maternal and neonatal epidemiological, clinical, and obstetric } \\
\text { characteristics, as well as the use of a pacifier, food allergies, Down } \\
\text { syndrome, cystic fibrosis, PKU, or autism }\end{array}$ \\
\hline Infant development & $\begin{array}{l}\text { Assessment of children's development and skills. Instrument: Survey of } \\
\text { Wellbeing of Young Children * }\end{array}$ \\
\hline $\begin{array}{l}\text { Use of vitamin supplements at the time of the interview and in the } \\
\text { last six months }\end{array}$ & $\begin{array}{l}\text { Current use of supplements and details on purchase place, person that } \\
\text { prescribed them, reason for use, and dosage }\end{array}$ \\
\hline $\begin{array}{l}\text { Total fertility rate, prenatal care, and information on breastfeeding } \\
\text { practices with the youngest child in the household }\end{array}$ & $\begin{array}{c}\text { Details on number of pregnancies, live births, prenatal visits, and } \\
\text { breastfeeding practices in the youngest child }\end{array}$ \\
\hline Home cooking & Elements of cooking skills and task-sharing in the kitchen \\
\hline Information on home food environment & $\begin{array}{c}\text { Availability and affordability of certain foods in the home environment } \\
\text { and parental feeding practices. Instrument: Comprehensive Feeding } \\
\text { Practices Questionnaire (part) ** }\end{array}$ \\
\hline Community food environment & $\begin{array}{l}\text { Availability and affordability of certain foods in the household's } \\
\text { surrounding territory }\end{array}$ \\
\hline Food insecurity situation & $\begin{array}{l}\text { Assessment of food and nutritional security. Instrument: Brazilian Food } \\
\text { Insecurity Scale } * \star \star\end{array}$ \\
\hline
\end{tabular}

\footnotetext{
* Source: Moreira et al. 15;

** Source: Musher-Eizenman \& Holub 16 and Mais et al. 17;

*** Source: Damacena et al. 34.
}

occurred. The participating state and municipal administrators received memoranda and informational materials on the survey and the number of households and census tracts to be visited.

At the beginning of each wave of data collection, videoconferences were held with the participation of the Executive Committee of ENANI-2019, representatives from the General Division of Food and Nutrition (CGAN) of the Ministry of Health, the ENANI-2019 communications consultancy, and municipal and state health and social assistance administrators for the presentation of the study and discussion of the details. The communications consultancy promoted more than 500 spontaneous insertions in media channels, including national and local press, national and local television stations, radio stations, and online vehicles. Four institutional videos on ENANI-2019 were produced with a presentation of the study and simulation of interviews, and which were posted on social media and the study's webpage (https://enani.nutricao.ufrj.br/) and sent to local administrators, interviewers, and participating families. This firm also advised the study's Executive Committee in the elaboration and execution of a contingency plan to solve misinformation crises caused by the dissemination of fake news during the fieldwork. 


\section{Figure 1}

Activities developed as of 2020 in the Brazilian National Survey on Child Nutrition (ENANI-2019).
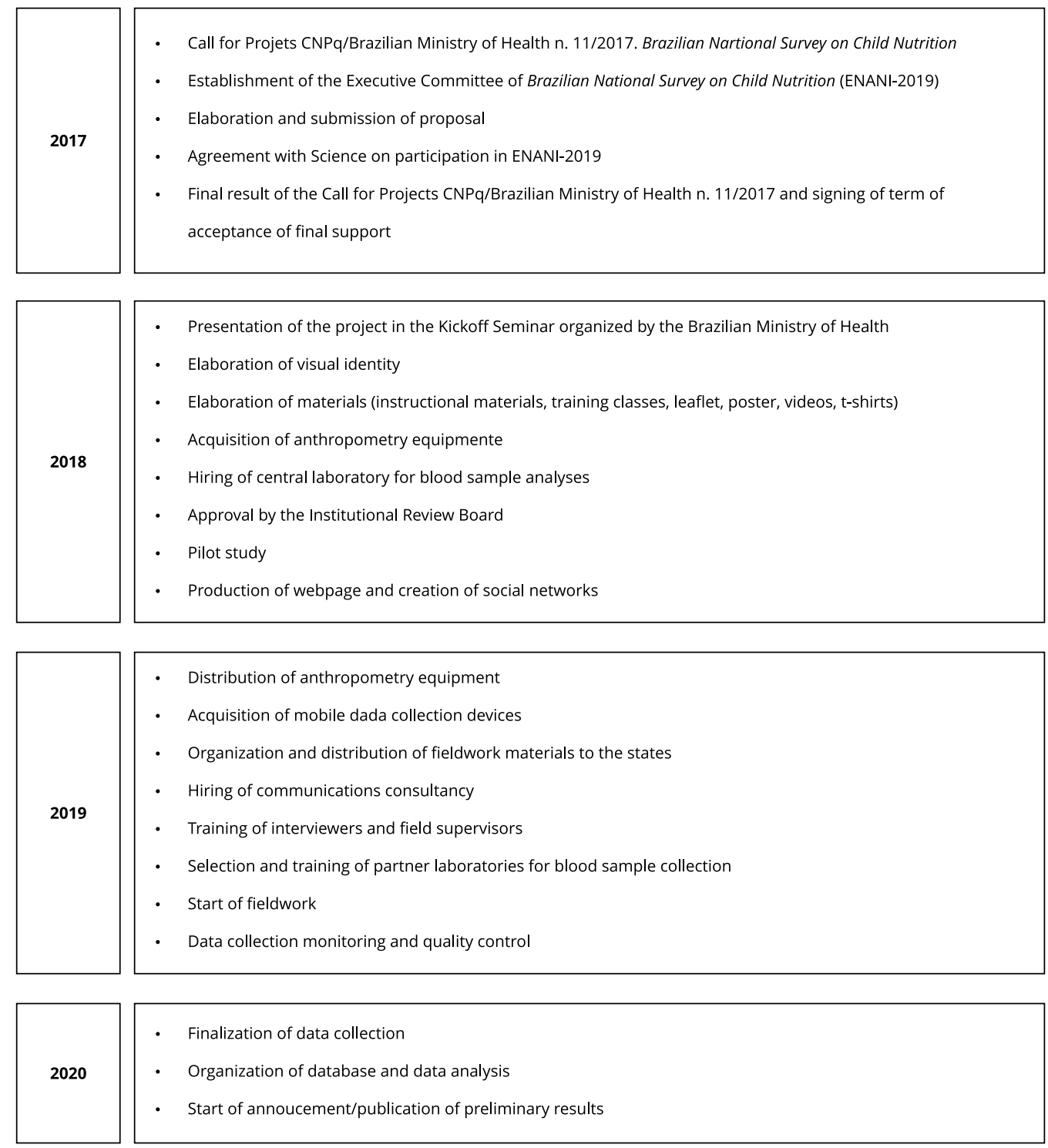

CNPq: Brazilian National Research Council; Science: Society for the Development of Scientific Research.

\section{Ethical aspects}

ENANI-2019 was approved by the Institutional Review Board of the Clementino Fraga Filho University Hospital of the Federal University of Rio de Janeiro (UFRJ) and was registered under number CAAE 89798718.7.0000.5257. The study was conducted according to the principles of good clinical practices, oriented by the Declaration of Helsinki, and complied with the ethical principles established by Resolution n. 466/2012 of the Brazilian National Health Council. 
The parents or guardians of the children that agreed to participate in the survey signed two copies of the informed consent form, freely and spontaneously, after hearing an explanation of all the ethical issues of the study. Participants were also consulted about their agreement to having biological specimens stored for future research.

The results of the anthropometric assessment of the child and biological mother and the child's blood tests were posted on the project's website for consultation by the parents/guardians via an individual login, per child, delivered to the family on the day of the data collection. The results were also returned by e-mail, social media messages, and a message app (WhatsApp) or printed via mail to the household, in case it was requested by the children's parents or guardians.

All children and biological mothers with anthropometric assessment indicative of malnutrition or obesity and children with altered laboratory parameters of anemia or vitamin A deficiency received a referral letter for care in health units under the SUS.

\section{Data collection}

\section{- Data collection teams}

Selection of households, the interviews, and the anthropometric measurements were performed by the interviewers recruited by Science, a nonprofit civil society organization founded by faculty members from the National School of Statistical Sciences (ENCE) and the Brazilian Institute of Geography and Statistics (IBGE) with experience in data collection in national surveys. The team hired by Science included 27 state coordinators, 30 field supervisors, and 323 interviewers distributed in each state according to the sample size.

The state coordinators were responsible for the following activities: recruitment of supervisors and interviewers; receiving and controlling study materials and equipment (mobile data collection devices or MDC, scales, infantometers, anthropometers, informed consent forms, publicity materials, leaflets and posters for distribution among the fieldwork teams); sending all the signed consent forms to Science; and other operational activities for proper conduction of the data collection.

Field supervisors were responsible for the following: organization of their teams' fieldwork, onsite supervision of the interviews to ensure strict compliance with protocols; awareness-raising on the study's importance with the eligible families and managers of buildings selected for the study; follow-up of coverage of the census tracts; supervision and quality control during the data collection; and other operational activities.

Interviewers were responsible for the following: updating the addresses of the households in each census tract in their work area, through the Census Tract Address Updating System (SAES) 11; visits to households; obtaining consent from the children's parents or guardians; interviews and 24HR 19; anthropometric data collection from the children and biological mothers 20; scheduling and accompanying the team responsible for the blood sample collection in the households 21; and other necessary tasks.

Supervisors and interviewers were identified with name badges and wore standardized t-shirts. The data collection material used by the interviewers consisted of a backpack containing an anthropometer/infantometer and a digital scale; tote cart for pulling the backpack; MDC; and various print materials (posters, leaflets with orientation on blood sample collection, letters of introduction explaining the survey), and informed consent forms to be signed by the children's parents or guardians. The supervisors' data collection material was an MDC.

The central clinical test laboratory hired for the study (Diagnósticos do Brasil; https://www. diagnosticosdobrasil.com.br) was responsible for selecting, recruiting, and training the teams in the partner laboratories that performed the blood sample collection in the 123 selected municipalities, organizing the household blood sample collection process, transporting the samples, performing the biochemical analyses, and generating the blood test results 21 . 


\section{- Data collection flow}

On the first visit, after the consent form was signed, the following were performed: interview and 24HR 19; anthropometric measurements of biological mothers and children two years and older (body mass and length/stature) 20; scheduling of blood sample collection for children at least six months of age, considering the parent's or guardian's availability and the partner laboratory's agenda; orientation about the day of the blood sample collection, as per instructions in the leaflet given to the family 21 . On the second visit, besides the blood sample collection in eligible children, anthropometric measurement was performed in the children under two years of age (Figure 2).

\section{Figure 2}

Data collection stages. Brazilian National Survey on Child Nutrition (ENANI-2019).
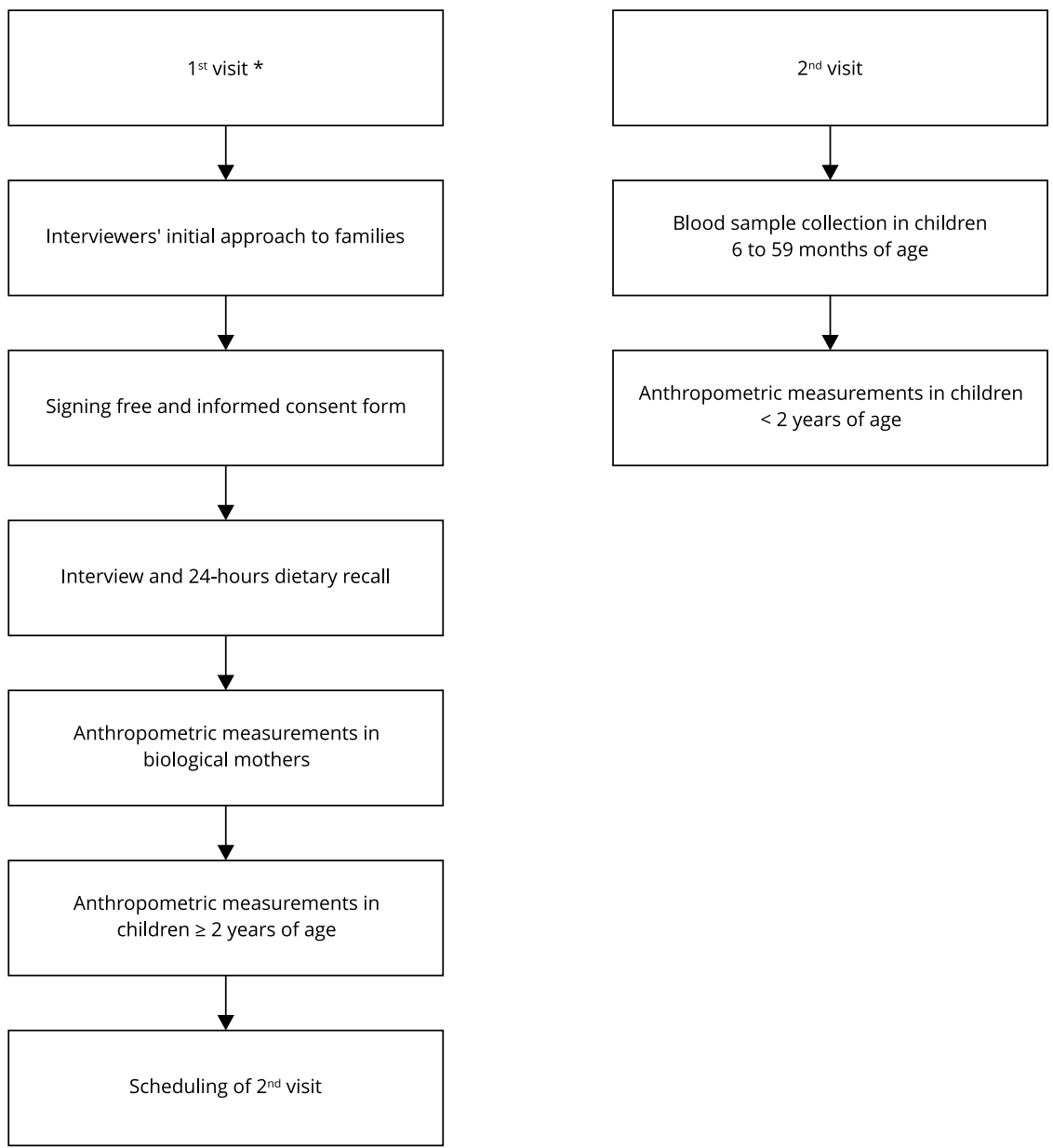

* In some cases the interviewer had to return to the household to finalize the data collection after the first visit. 


\section{- Data collection system}

The data collection used the Computer-Assisted Personal Interviewing (CAPI) method with the support of an MDC for automatic identification of the interviewer, day of collection, and location of the household; an indication of the sequential list of households to visit; and execution of the questionnaire's data capture program.

The software Census and Survey Processing System (CSPro; https://www.census.gov/data/soft ware/cspro.html), a shareware system developed by the U.S. Census Bureau, was used to create the CAPI 22. The data capture system was built considering smart completion (relationship between questions and "skip" logics), with minimum and maximum expected values and mandatory responses, besides alerts on implausible answers, contributing to the quality control during the questionnaire's completion. The MDC included the SAES, the general questionnaire, the 24HR application software (24HR-App), manuals, and videos used in the training activities.

The collected data were encrypted and transmitted via internet at the end of each day to a central server via synchronizing the MDC with the Science server. The MDC used in census tracts with high rates of violence were equipped with internet data packages for immediate data transmission after collection to minimize the risk of data loss in case of theft of the MDC. All the systems and information stored in the MDC were password-protected to safeguard the interviewees' data in case of theft or loss of the device.

\section{Quality assurance and control}

The quality assurance and control procedures aimed to decrease the odds of random and systematic errors in measurement and database construction. These procedures were based on the literature 23 and the accumulated and documented experience in previous Brazilian surveys such as the Longitudinal Study of Adult Health (ELSA-Brasil) 24 and the Study of Cardiovascular Risks in Adolescents (ERICA) 25. In ENANI-2019, an independent assessment was performed in 10\% of the sample, applying a simplified interview and verifying whether the visits to the households were being performed according to the protocol. The supervisor conducted this independent assessment in the sample census tracts after the interviewer's work in the tract was finished. Due to the data collection's interruption with the COVID-19 pandemic, 482 (38.4\%) tracts did not have the independent assessment done. Specific quality assurance and control procedures for each study domain are described in Lacerda et al. ${ }^{19}$, Anjos et al. 20, and Castro et al. 21.

\section{- Development of the protocol, manuals, and support materials}

A study protocol was developed with the objectives, design, sample size, the set of relevant instruments, and a detailed description of all the stages. The general questionnaire consisted of a $24 \mathrm{HR}$ and 20 sections of questions on specific topics. All the materials were developed specifically for the ENANI-2019 by the Executive Committee and the study's post-doctoral researchers, with support from the expert groups in the three thematic domains.

The general questionnaire's manual 26 covers the complete fieldwork flow. It addresses orientation on the interviewer's personal appearance and demeanor, presenting the study at the household and collecting informed consent, on the procedures to deal with refusals, completing all sections in the general questionnaire, and describing the basic kit for conducting the data collection. The $24 \mathrm{HR}$ manual 27 aimed at the interviewer standardizing the 24HR and includes the instrument's objective, the recommended five steps for its application, the interviewer's attitudes, and detailed instructions on using the 24HR-App and the Photographic Manual for Quantification of Children's Dietary Intake 28. The anthropometry manual presents the anthropometric data collection procedures in children and biological mothers and covers overall aspects for taking measurements and information on preparation of the equipment, measurement techniques, including in special situations, quality assessment of the measurements, and equipment maintenance 29 . The manual on blood sample collection and transportation of biological samples provides operational orientation for the central and partner 
laboratory teams for collecting and processing the biological specimens, conducting the biochemical analyses, and supporting the anthropometric assessment procedures 30.

Posters were produced to announce the study, plus a leaflet that was delivered on the first visit to the household with orientation on the procedures for performing the blood sample collection and receiving the laboratory test results and anthropometric measurement.

\section{- Pretest and pilot study with instruments and procedures}

The study instruments were pretested and refined until they were considered ready for use in the pilot study. The latter was conducted in six census tracts in the city of Rio de Janeiro and four tracts in Macaé (Rio de Janeiro State), with up to 10 interviews per tract. The households were selected with the inverse sampling procedure. The data collection control system was tested to record the result of the visit to each address (interview performed versus various types of non-response) and furnish new addresses in case the 10 interviews were not conducted with the 20 households initially listed. The logistics for scheduling, performing blood sample collection, transportation of the biological specimens, and delivering test results to the child's parents or guardians were also tested in the pilot study. The pilot study's results were used to refine the instruments and procedure flows.

\section{- Data consistency analysis}

During the fieldwork, procedures were adopted to assess the data quality concerning missing data, inconsistencies, and detection of extreme and implausible values not detected by the critical system programmed in the MDC. Some procedures adopted for data monitoring were:

(a) Creation of a dashboard in the R software (http://www.r-project.org), Shiny package for continuous monitoring of the following indicators by state, municipality, and census tract: situation (data collection concluded or in progress; percentage of tracts finalized), number of visits, the proportion of refusals, expected and completed interviews, completeness rate, success rate, number and proportion of blood sample collections and repeat collections, number of anthropometric assessments, and mean duration of the interview.

(b) Analysis of missing or inconsistent data in the questionnaire, simultaneously with the data collection. With the early detection and identification of the source of errors, procedures were implemented, and the interviewers received orientation to address them.

(c) Assessment of the occurrence of last-digit preference for anthropometric measurements in each interviewer, after accumulation of at least 100 measurements and identifying extreme anthropometric values in the children. Interviewers were advised on the importance of recording the value obtained in full and repeating the measurements in case of implausible values.

For each procedure performed, data analysis routines were created in Stata version 15.0 (https:// www.stata.com). Weekly reports were generated with the data analyses. Whenever inconsistencies were identified, the coordinators and state supervisors were advised to monitor the interviewers' collection procedures, or if necessary, to retrain or relocate the interviewer. The interviewer or supervisor returned to the interviewed household to verify the inconsistent information and repeat the children's anthropometric measurements when necessary.

\section{Training for data collection}

For the data collection and anthropometric measurements, all the state coordinators, supervisors, and field interviewers were trained. The training occured in two stages, the central training (combining teams from two to five states) and the anthropometry training (with each state's team), administered in all the state capitals. Seven central trainings were conducted: Rio de Janeiro, Belo Horizonte (Minas Gerais State), Curitiba (Paraná State), Manaus (Amazonas State), São Paulo, Belém (Pará State), and Recife (Pernambuco State); and 27 anthropometry trainings, administered by the Executive Committee of ENANI-2019 and by local professors from universities collaborating in the study. Details on the anthropometry training are provided in Anjos et al. 20. 


\section{- Central training}

Each training lasted 40 hours, distributed across five consecutive days. The following course content was administered: basic concepts used in household surveys (census tract, household, resident, updating addresses, selection of census tracts to visit, contact techniques); use of the MDC (basic use, dealing with unique situations, and image capture); presentation of each of the survey's sections of questions and each question's purpose; $24 \mathrm{HR}$ procedures 19 ; logistics of blood sample collection (teams involved, procedures by the Science team with the child's parents, and laboratory responsible for the blood sample collection) 21 ; and communication strategies prior to and during data collection. A dialogical approach was used with these course contents, using explanatory slides and videos, followed by exercises and simulated practices (for each stage and the complete interviews).

\section{Results}

Data collection occurred in 123 Brazilian municipalities, including the state capitals and the Federal District. A total of 193,212 households were visited, of which 19,540 (10.1\%) were eligible. In the 12,524 participating households, 14,558 children under five years of age and 12,155 biological mothers were studied, of which 11,282 (92.8\%) and 11,284 (92.8\%) had body mass and stature measured, respectively. Of all the children studied, 14,541 (96.9\%) had information on 24HR, and 13,990 (96.1\%) and 13,921 (95.6\%) had body mass and length/stature measured, respectively. Of the 12,598 eligible children for blood sample collection (6 to 59 months), 8,739 (69.3\%) had at least one laboratory parameter assessed (Figure 3). Details on the losses in blood sample collection are provided in Castro et al. 21 .

When the data collection was interrupted, the study's coverage rates by geographic region were the following: North, 75.5\%; Northeast, 81\%; Southeast, 87.6\%; South, 83.9\%; and Central West, 89.4\%. Considering seasonality, the highest proportions of interviews occurred in the autumn (33.1\%) and winter (28.7\%), compared to the spring (20.1\%) and summer (18.1\%).

The survey experienced a refusal rate of $35.8 \%$, considering only the selected and contacted eligible households. Considering the total households visited as the denominator, the refusal rate was $3.7 \%$. Of the final sample of children under five years of age included in the study, $13.5 \%(\mathrm{n}=1,960)$ were under 6 months of age, 29.9\% $(n=4,362)$ were $6-23.9$ months of age, and $56.6 \%(n=8,236)$ were 24-59.9 months of age. The proportion of children according to age group by major geographic region was similar to the national distribution (Figure 4).

\section{Discussion}

ENANI-2019 assessed 14,558 children under five years of age according to rigorous protocols, facing various challenges for executing all the planned procedures. The total fertility rate projected by the IBGE for the Brazilian population in 2018 was 1.77 children per woman 31 and has decreased in recent decades, reflected directly by the researchers' difficulty finding households with children under five years of age. The total number of households visited was approximately 13 times greater than the 15,000 households determined in the sampling plan. This greater data collection effort led to a longer duration of the survey and was determinant for the uneven distribution of interviews between seasons of the year. This aspect needs to be considered in the analyses since it can impact the interpretation of data on dietary intake and some biochemical markers 12,13.

The selection and implementation of the study sample included census tracts located in areas with high levels of urban violence, with the presence of armed militias and drug trafficking. In several of these tracts, the interviewers reported difficulty conducting the survey, which required the development of solutions to avoid compromising the representativeness of different income classes in the sampling plan while guaranteeing the data collection teams' safety and physical integrity. The propor- 


\section{Figure 3}

Data collection flowchart. Brazilian National Survey on Child Nutrition (ENANI-2019).

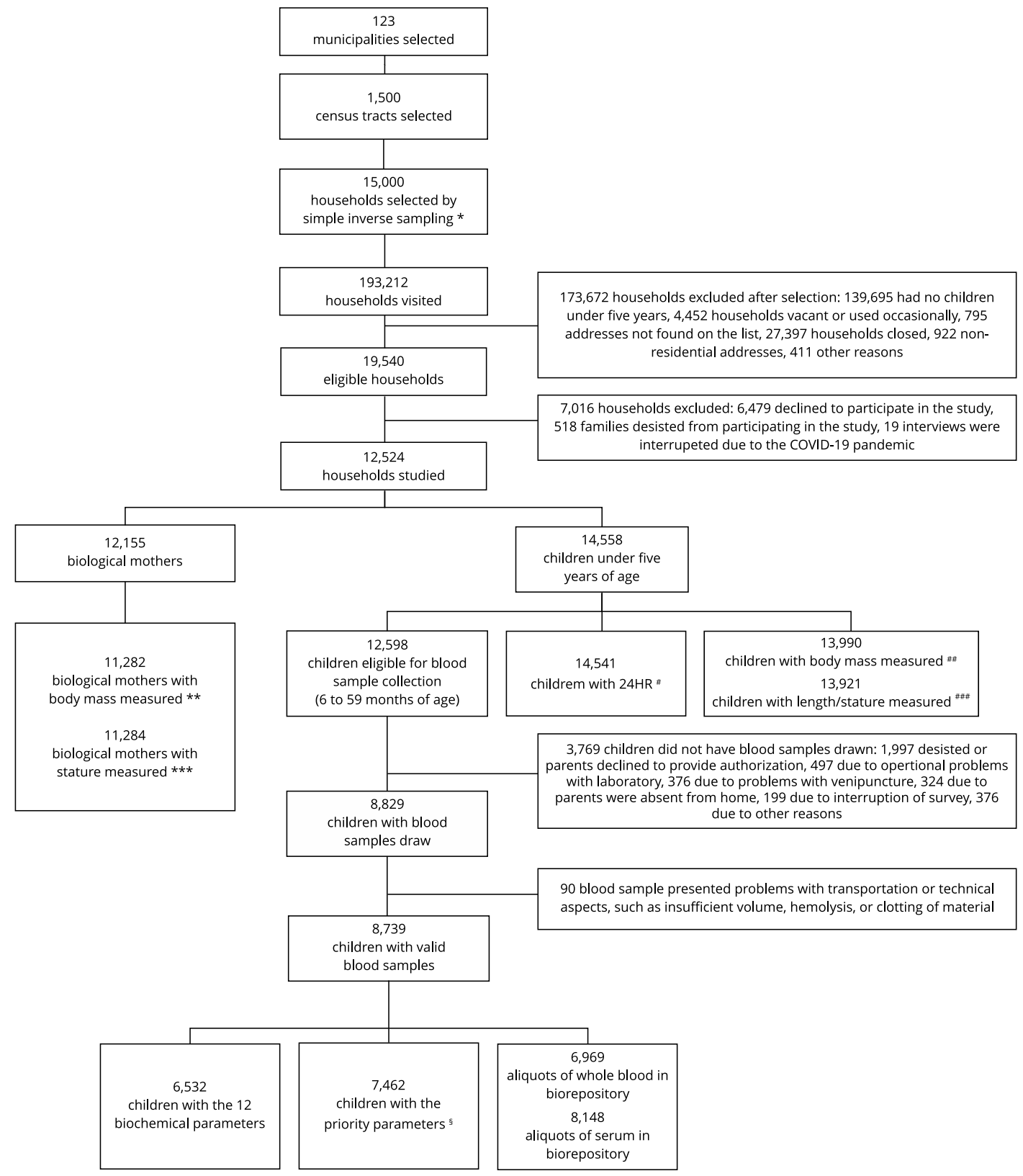

24HR: 24-hour dietary recall.

* 10 households were selected in each census tract;

** 873 biological mothers without body mass measured: away from home or illness $(n=351,40 \%)$, refusal $(n=305,35 \%)$, other reasons $(n=217,25 \%)$;

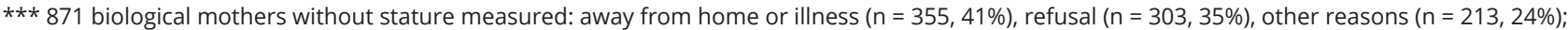

\# 17 children without 24HR completed;

\#\# 568 children without body mass measured: away from home or illness $(n=251,44 \%)$, refusal by the child or parent/guardian ( $n=163,29 \%)$, other reasons $(n=154,27 \%)$;

\#\#\# 637 children without length/stature measured: away from home or illness $(n=253,40 \%)$, refusal by the child or parent/guardian ( $n=225,35 \%)$, other reasons $(n=159,25 \%)$;

$\S$ Priority parameters for the Brazilian Ministry of Health: complete blood count, ferritin, vitamin A, and C-reactive protein. 
Figure 4

Proportion of interviews completed in Brazil as a whole and major geographic regions by age group. Brazilian National Survey on Child Nutrition (ENANI-2019).

4a) Brazil

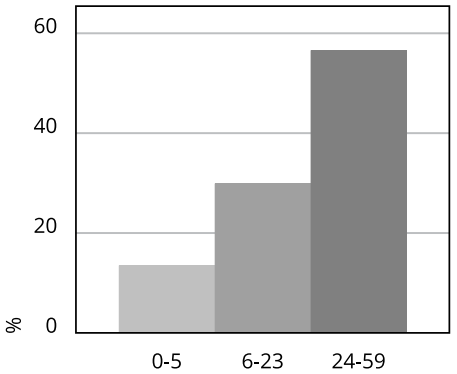

4d) Southeast

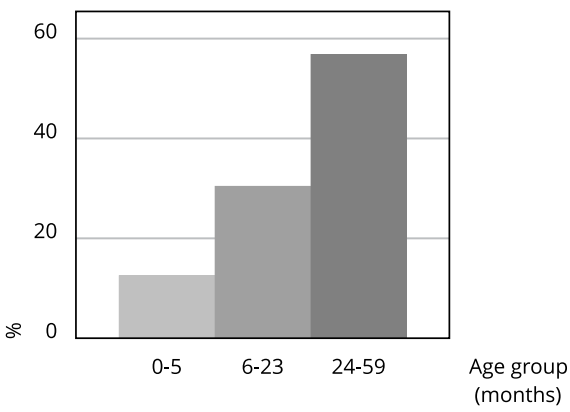

4b) North
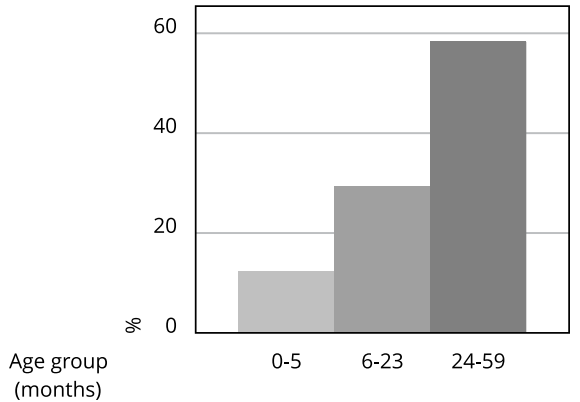

4e) South

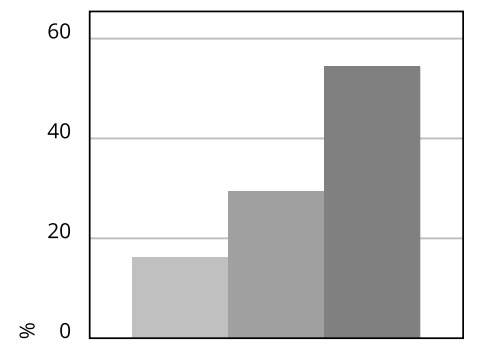

$0-5$ 4c) Northeast

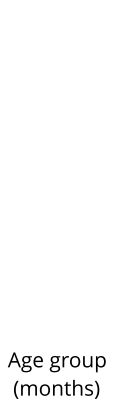

4f) Central West

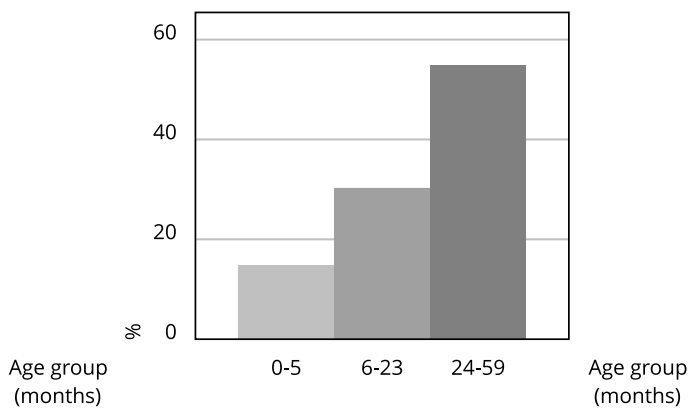

tion of refusals in the households visited by ENANI-2019 was much lower than in other household surveys such as the PNDS/1996 (13.5\%), PNDS/2006 (10.8\%), POF 2008/2009 (11\%), and PNS/2013 (20\%) 6,32,33,34.

The interruption of the fieldwork before reaching the calculated sample of 15,000 households due to the COVID-19 pandemic limited the ultimate sample size 11. Still, the sample of children available for the test analyses is only slightly smaller than initially planned. Thus, the impact on the estimates' precision for the entire country is negligible. Meanwhile, for the regional analyses, the North of Brazil has smaller samples than the other regions. At any rate, the calibrated sampling weights will correct this sampling loss.

Hiring the communications consultancy at the beginning of the project rather than later may have strategically supported the entire information management involved in the study and anticipated situations of misinformation crisis. Such misinformation claimed that the ENANI-2019 interviewers were associated with groups that allegedly kidnapped children, stole organs, or transmitted infectious diseases with the syringes used in the venipuncture. The communication strategies in ENANI-2019, such as social media, a toll-free telephone hotline, the webpage, press coverage, and direct communication with local government agencies, helped disseminate true and trustworthy information and announce the study. The mobilization of state and municipal administrators fostered better linkage with the primary healthcare network and community health agents for raising families' awareness to participate in the survey. 
Blood sample collection in children 6 to 59 months of age was another challenge. It required convincing the family of its importance, the phlebotomist's skill and experience, and all aspects related to the logistics of transporting and analyzing the specimens 21.

There were positive and innovative points in planning and executing the study. The training activities administered by the Executive Committee of ENANI-2019 and Science teams were carefully prepared and distributed across a sufficient course hour load to cover the study's complexity, with a positive impact on the data quality. The system for returning the results to participants, including the anthropometry assessment and laboratory tests, with referral to healthcare units whenever necessary, guaranteed the Executive Committee's ethical commitment to the families.

The use of adequate anthropometric equipment for the fieldwork's characteristics facilitated the interviewers' work, especially in the body mass measurements with digital scales 20 . The development of a $24 \mathrm{HR}$-App, associated with a photographic manual 28 conceived for the target age group contributed to the standardized data collection on dietary intake 19.

Another innovative aspect included indicators on nationally unprecedented breastfeeding practices such as milk donation to human milk banks and cross-nursing ${ }^{19}$ and topics such as home cooking and home and community food environment.

ENANI-2019 will produce scientific evidence as an important milestone for the elaboration and follow-up of actions, programs, and public policies for childhood food and nutrition in keeping with the PNSAN 2, PNAN 1, and the Brazilian National School Feeding Plan (PNAE) 35. Examples of such actions include promotion, support, and protection for breastfeeding, adequate management of complementary feeding, promotion of adequate and healthy diet in different spaces and networks, prevention and control of micronutrient deficiencies, and provision of food and income to vulnerable groups.

\section{Final remarks}

ENANI-2019 is the first nationwide survey in Brazil that assessed breastfeeding practices, complementary feeding, individual dietary intake, anthropometric nutritional status, and micronutrient deficiencies in children under five. The results will allow comparisons with previous studies, and due to their thematic scope, the findings will expand the understanding of dietary and nutritional patterns in the national scenario. The scientific evidence produced by the survey will help fill knowledge gaps and back strategic decisions for implementing public policies in food and nutrition.

Considering the great potential of the collected information, the Executive Committee of ENANI-2019 will provide the scientific community with timely access to all the data produced and the ancillary documents, in keeping with the principles of open science and optimal use of data collected with public resources. 


\section{Contributors}

N. H. Alves-Santos, I. R. R. Castro, L. A. Anjos, E. M. A. Lacerda, C. S. Boccolini, and G. Kac contributed to the study conception and design, and to the article's writing and review. P. Normando, M. B. Freitas, and D. R. Farias contributed to the article's writing and review. M. T. L. Vasconcellos and P. L. N. Silva contributed to the sampling of the study and to the article's writing and review. All authors approved the final version of the article.

\section{Additional informations}

ORCID: Nadya Helena Alves-Santos (0000-00020098-6047); Inês Rugani Ribeiro de Castro (00000002-7479-4400); Luiz Antonio dos Anjos (00000002-5257-6912); Elisa Maria de Aquino Lacerda (0000-0002-1830-4278); Paula Normando (00000002-6443-7733); Maiara Brusco de Freitas (00000003-1737-8918); Dayana Rodrigues Farias (00000003-0278-8375); Cristiano Siqueira Boccolini (0000-0002-4804-5641); Maurício Teixeira Leite de Vasconcellos (0000-0003-1658-2589); Pedro Luis do Nascimento Silva (0000-0002-9378-7986); Gilberto Kac (0000-0001-8603-9077).

\section{Acknowledgments}

To the professors of Brazilian universities who collaborated in the planning of the research. To the institutions that allowed the central training to be carried out on their premises (Rio de Janeiro State Univesity - UERJ; Minas Gerais Federal University - UFMG; Paraná Federal University - UFPR; Amazonas Federal University - UFAM; São Paulo State University - USP; Pará Federal University - UFPA; and Pernambuco Federal University - UFPE). To the participating families who made this study possible. To Talita Berti, Juliana Mello, Keronlainy Salvatte, Ana Beatriz Rodrigues, and Letícia Ramos for their support in the fieldwork and organization of the database. To the Brazilian Ministry of Health/ Brazilian Nacional Research Council (CPNq) - process: 440890/2017-9.

\section{References}

1. Departamento de Atenção Básica, Secretaria de Atenção à Saúde, Ministério da Saúde. Política nacional de alimentação e nutrição. 2ạ Ed. Brasília: Ministério da Saúde; 2007. (Textos Básicos de Saúde).

2. Brasil. Decreto no 7.272 , de 25 de agosto de 2010. Regulamenta a Lei no 11.346 , de 15 de setembro de 2006, que cria o Sistema Nacional de Segurança Alimentar e Nutricional - SISAN com vistas a assegurar o Direito Humano à Alimentação Adequada, institui a Política $\mathrm{Na}$ cional de Segurança Alimentar e Nutricional PNSAN, estabelece os parâmetros para a elaboração do Plano Nacional de Segurança Alimentar e Nutricional, e dá outras providências. Diário Oficial da União 2010; 26 ago.

3. Priore SE, Gontijo C, Faria E, Faria F, Cecon $\mathrm{R}$, Franceschini S. Inquéritos nacionais de antropometria e consumo alimentar. In: Taddei JA, Lang RMF, Silva GL, Toloni MHA, Vega JB, organizadores. Nutrição em saúde pública. 2a Ed. Rio de Janeiro: Rubio; 2016. p. 75-112.

4. Interdepartmental Committee on Nutrition for National Development. Northeast Brazil: nutrition survey, March-May 1963. Washington DC: Interdepartmental Committee on Nutrition for National Development; 1965.

5. Sperandio N, Priore SE. Inquéritos antropométricos e alimentares na população brasileira: importante fonte de dados para o desenvolvimento de pesquisas. Ciênc Saúde Colet 2017; 22:499-508.

6. Ministério da Saúde. Pesquisa Nacional de Demografia e Saúde da Criança e da Mulher PNDS 2006: dimensões do processo reprodutivo e da saúde da criança. Brasília: Ministério da Saúde, 2009.

7. Rosén BA. A user's guide to Pareto $\pi$ ps sampling. Stockholm: Statistiska Centralbyrån; 2000.

8. Haldane JBS. On a method of estimating frequencies. Biometrika 1945; 33:222-5.

9. Vasconcellos MTl, Silva PLN, Szwarcwald CL. Sampling design for the World Health Survey in Brazil. Cad Saúde Pública 2005; 21 Suppl:S89-99.

10. Vasconcellos MTL, Silva PLN, Anjos LA. Sample design for the Nutrition, Physical Activity and Health Survey (PNAFS), Niterói, Rio de Janeiro, Brazil. Estadística 2013; 65:47-61.

11. Vasconcellos MTL, Silva PLN, Castro IRR, Boccolini CS, Alves-Santos NH, Kac G. Sampling plan of the Brazilian National Survey on Child Nutrition (ENANI-2019): a populationbased household survey. Cad Saúde Pública 2021; 37:e00037221.

12. Holick MF. The vitamin D deficiency pandemic: approaches for diagnosis, treatment and prevention. Rev Endocr Metab Disord 2017; 18:153-65.

13. Stelmach-Mardas M, Kleiser C, Uzhova I, Peñalvo JL, La Torre G, Palys W, et al. Seasonality of food groups and total energy intake: a systematic review and meta-analysis. Eur J Clin Nutr 2016; 70:700-8. 
14. Barros AJ, Victora CG. Indicador econômico para o Brasil baseado no censo demográfico de 2000. Rev Saúde Pública 2005; 39:523-9.

15. Moreira RS, de Castro Magalhães L, Siqueira CM, Alves CRL. Adaptação transcultural do instrumento de vigilância do desenvolvimento infantil "Survey of Wellbeing of Young Children (SWYC)" no contexto brasileiro. J Hum Growth Dev 2019; 29:28-38.

16. Musher-Eizenman D, Holub S. Comprehensive Feeding Practices Questionnaire: validation of a new measure of parental feeding practices. J Pediatr Psychol 2007; 32:960-72.

17. Mais LA, Warkentin S, Latorre MR, Carnell S, Taddei JA. Validation of the Comprehensive Feeding Practices Questionnaire among Brazilian families of school-aged children. Front Nutr 2015; 2:35.

18. World Health Organization. WHO child growth standards: length/height for age, weight-forage, weight-for-length, weight-for-height and body mass index-for-age, methods and development. Geneva: World Health Organization; 2006.

19. Lacerda EMA, Boccolini CS, Alves-Santos NH, Castro IRR, Anjos LA, Crispim SP, et al. Methodological aspects in the assessment of dietary intake in the Brazilian National Survey on Child Nutrition (ENANI-2019): a population-based household survey. Cad Saúde Pública 2021; 37:e00301420.

20. Anjos LA, Ferreira HS, Alves-Santos NH, Freitas MB, Boccolini CS, Lacerda EMA, et al. Methodological aspects of anthropometric assessment in the Brazilian National Survey on Child Nutrition (ENANI-2019): a populationbased household survey. Cad Saúde Pública 2021; 37:e00301420.

21. Castro IRR, Costa PNR, Alves-Santos NH, Bezerra FF, Reis MC, Schwarzschild LFCP, et al. Methodological aspects of micronutrient assessment in the Brazilian National Survey on Child Nutrition (ENANI-2019): a populationbased household survey. Cad Saúde Pública 2021; 37:e00301120.

22. Abelsaeth A. Tutorial: development of data entry- and CAPI applications in CSPro. Oslo: Norway Statistics; 2012.

23. Szklo M, Javier Nieto F. Epidemiology: beyond the basics. Burlington: Jones \& Bartlett Learning; 2014.

24. Schmidt MI, Griep RH, Passos VM, Luft VC, Goulart AC, Menezes GMS, et al. Estratégias e desenvolvimento de garantia e controle de qualidade no ELSA-Brasil. Rev Saúde Pública 2013; 47:105-12.

25. Bloch KV, Szklo M, Kuschnir MCC, de Azevedo Abreu G, Barufaldi LA, Klein $\mathrm{CH}$, et al. The Study of Cardiovascular Risk in Adolescents - ERICA: rationale, design and sample characteristics of a national survey examining cardiovascular risk factor profile in Brazilian adolescents. BMC Public Health 2015; 15:94.
26. Universidade Federal do Rio de Janeiro. Manual do questionário geral: ENANI - Estudo Nacional de Alimentação e Nutrição Infantil. https://enani.nutricao.ufrj.br/wp-content/ uploads/2020/07/Manual_questionarioGeral -ENANI-2.pdf (accessed on 18/May/2020).

27. Universidade Federal do Rio de Janeiro. Manual do recordatório de 24 horas: ENANI Estudo Nacional de Alimentação e Nutrição Infantil. https://enani.nutricao.ufrj.br/wp-con tent/uploads/2020/07/Manual-R24h-desaco plado-1.pdf (accessed on 18/May/2020).

28. Crispim SP, Kac G, Lacerda EMA, Castro IRR. Manual fotográfico de quantificação alimentar infantil. Curitiba: Universidade Federal do Paraná; 2018

29. Universidade Federal do Rio de Janeiro. Manual do antropometria: ENANI - Estudo Nacional de Alimentação e Nutrição Infantil. https://enani.nutricao.ufrj.br/wp-content/ uploads/2020/07/Manual-de-Avaliacao-An tropometrica.pdf (accessed on 18/May/2020).

30. Diagnósticos do Brasil. Manual de procedimentos de coleta e envio de amostras: ENANI Estudo Nacional de Alimentação e Nutrição Infantil. https://enani.nutricao.ufrj.br/wp-con tent/uploads/2020/07/Manual-de-ColetaENANI.pdf (accessed on 18/May/2020).

31. Instituto Brasileiro de Geografia e Estatística. Projeções da população: Brasil e unidades da federação: revisão 2018. 2a Ed. Rio de Janeiro: Instituto Brasileiro de Geografia e Estatística; 2018.

32. Sociedade Civil Bem-Estar Familiar no Brasil. Pesquisa Nacional sobre Demografia e Saúde. Rio de Janeiro: Sociedade Civil Bem-Estar Familiar no Brasil/Demographic and Health Surveys; 1997.

33. Instituto Brasileiro de Geografia e Estatística. Pesquisa de Orçamentos Familiares 2008-2009: análise do consumo alimentar pessoal no Brasil. Rio de Janeiro: Instituto Brasileiro de Geografia e Estatística; 2011.

34. Damacena GN, Szwarcwald CL, Malta DC, Souza Júnior PRB, Vieira MLFP, Pereira CA, et al. O processo de desenvolvimento da Pesquisa Nacional de Saúde no Brasil, 2013. Epidemiol Serv Saúde 2015; 24:197-206.

35. Brasil. Lei no 11.947, de 16 de junho de 2009. Dispõe sobre o atendimento da alimentação escolar e do Programa Dinheiro Direto na Escola aos alunos da educação básica; altera as Leis no 10.880 , de 9 de junho de 2004, 11.273, de 6 de fevereiro de 2006, 11.507, de 20 de julho de 2007; revoga dispositivos da Medida Provisória no $2.178-36$, de 24 de agosto de 2001, e a Lei no 8.913 , de 12 de julho de 1994; e dá outras providências. Diário Oficial da União 2009; 17 jun. 


\section{Resumo}

O objetivo deste artigo é apresentar aspectos metodológicos gerais do Estudo Nacional de Alimentação e Nutrição Infantil (ENANI-2019), desde a concepção do desenho da pesquisa até o detalhamento da coleta dos dados. Trata-se de um inquérito populacional de base domiciliar com amostra calculada de 15 mil domicílios para identificação de crianças menores de 5 anos de idade, realizado em 123 municípios dos 26 estados brasileiros e do Distrito Federal. O ENANI-2019 engloba dados de práticas de aleitamento materno e consumo alimentar; estado nutricional antropométrico das crianças e das mães biológicas; e estado nutricional para os seguintes micronutrientes: ferro (hemoglobina e ferritina), zinco, selênio $e$ as vitaminas $A, B 1, B 6, B 12, D, E$ e folato das crianças de 6 a 59 meses de idade. Foram visitados 193.212 domicílios, dos quais 19.951 eram elegíveis e 12.524 foram incluídos no estudo. Foram estudadas 14.558 crianças, sendo obtidas 13.990 $(96,1 \%)$ e 13.921 (95,6\%) medidas de massa corporal e comprimento/estatura, respectivamente; $e$ realizados $14.541(99,9 \%)$ recordatórios alimentares de 24 horas. Das 12.598 elegíveis para coleta de sangue, 8.739 (69,3\%) tiveram pelo menos um parâmetro laboratorial avaliado. Os dados foram coletados de fevereiro de 2019 a março de 2020, quando a pesquisa foi interrompida devido à pandemia de COVID-19. As evidências produzidas pelo ENANI-2019 poderão subsidiar a formulação, o acompanhamento e/ou o redirecionamento de políticas de alimentação e nutrição, tais como as de promoção do aleitamento materno e da alimentação saudável e as de prevenção e controle de diferentes formas de má nutrição.

Lactente; Pré-escolar; Métodos; Avaliação Nutricional

\section{Resumen}

El objetivo de este artículo es presentar aspectos metodológicos generales del Estudio $\mathrm{Na}$ cional de Alimentación y Nutrición Infantil (ENANI-2019) en Brasil, desde la concepción del diseño de la investigación, hasta el detalle de la recogida de datos. Se trata de una encuesta poblacional de base domiciliaria con una muestra calculada de 15.000 domicilios para la identificación de niños menores de cinco años de edad, realizado en 123 municipios de los 26 estados y en el Distrito Federal. El ENANI-2019 engloba datos de prácticas de lactancia materna y consumo alimentario; estado nutricional antropométrico de los niños y madres biológicas; así como el estado nutricional para los siguientes micronutrientes: hierro (hemoglobina y ferritina), zinc, selenio y vitaminas $A$, $B 1, B 6, B 12, D, E y$ ácido fólico en niños de 6 a 59 meses de edad. Se visitaron 193.212 domicilios, de los cuales 19.951 eran elegibles y 12.524 se incluyeron en el estudio. Se estudiaron a $14.558 \mathrm{ni}$ ños, obteniéndose $13.990(96,1 \%)$ y $13.921(95,6 \%)$ medidas de masa corporal y longitud/estatura, respectivamente; $y$ se realizaron 14.541 (99,9\%) recordatorios alimentarios de 24 horas. De las 12.598 muestras elegibles para recogida de sangre, 8.739 (69,3\%) contaron con por lo menos un parámetro de laboratorio evaluado. Los datos se recogieron de febrero de 2019 a marzo de 2020, cuando se interrumpió la investigación, debido a la pandemia de COVID-19. Las evidencias producidas por el ENANI-2019 podrán apoyar la formulación, seguimiento y/o redirección de políticas de alimentación y nutrición, como las de promoción de la lactancia materna y alimentación saludable, así como las de prevención y control de diferentes formas de mala nutrición.

Lactante; Preescolar; Métodos; Evaluación Nutricional
Submitted on $18 /$ Oct $/ 2020$

Final version resubmitted on 15/May/2021

Approved on 28/May/2021 